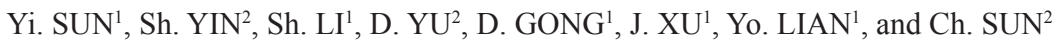

\title{
EFFECTS OF L-ARGININE ON SEIZURE BEHAVIOR AND EXPRESSION OF GFAP IN KAINIC ACID-TREATED RATS
}

\author{
Received September 15, 2012.
}

Rats i.p. injected once with $10 \mathrm{mg} / \mathrm{kg}$ kainic acid exhibited clear seizure behavior ("wet-dog shakes," rearing on the hindlimbs, and bilateral clonus). Pretreatment with L-arginine (L-Arg twice a day for 5 days) significantly decreased these manifestations. The medium dose of L-Arg (40 mg/kg) was found to be close to optimum; 10 and $160 \mathrm{mg} / \mathrm{kg} \mathrm{L}$-Arg provided much smaller positive effects. In KA-treated rats, a much higher density of GFAP-positive astrocytes was found in the hilus of the dorsal hippocampus, while $40 \mathrm{mg} / \mathrm{kg} \mathrm{L}$-Arg+KA-treated rats demonstrated noticeably weaker GFAP overexpression. The results of Western blotting analysis were fully comparable with those obtained in the immunostaining experiments.

Keywords: L-arginine, kainic acid, seizure behavior, GFAP.

\section{INTRODUCTION}

L-Arginine (L-Arg) first isolated in 1886 is one of the 20 most common natural amino acids. In mammals, arginine is classified as a semiessential or conditionally essential amino acid (depending on the developmental stage and health status of the individual) [1]. Preterm infants are unable to synthesize arginine internally, making this amino acid nutritionally essential for them [2]. There are some conditions that cause increased requires of the organism for the synthesis of L-arginine, including surgical or other trauma, sepsis, and burns. It should be taken into consideration that L-Arg is the substrate for nitric oxide (NO) synthesis.

Kainic acid (KA) is a natural organic acid existing in some seaweed. It is a specific agonist for the kainate receptors, a subtype of ionotropic glutamate receptors for which KA can imitate the effect of glutamate. Kainic acid is a potent stimulant of the CNS used for the induction of seizures in experimental animals; in particular, KA allows experimenters to build up a rat model of epilepsy. As was demonstrated earlier, NO may alleviate seizures and, thus, may be a kind of endogenous antiepileptics [3]. However, the mechanism of NO action in this respect still remains unclear.

\footnotetext{
${ }^{1}$ Department of Functions Physiology, Dalian Medical University, Dalian, China.

2 Institute for Brain Disorders, Dalian Medical University, Dalian, China. Correspondence should be addressed to Chang-kai Sun

(e-mail: cksun110@vip.sina.com).
}

It has been reported that reactive proliferation of astrocytes occurs during the process of neurodegeneration or brain injury, and this is accompanied by intensification of the synthesis of glial fibrillary acidic protein (GFAP), a cell-specific marker for reactive astrocytes [4-6]. Increased GFAP immunoreactivity [7-8] and the respective mRNA levels were found in seizure-manifesting rats [9-11]. The question whether L-Arg, an important component of the NO system, exerts any effect on the expression of GFAP has not yet been clarified. This is why we investigated the effects of L-Arg on seizure behavior and expression of GFAP in KA-treated rats.

\section{METHODS}

Animals and Treatments. Male Wistar rats (mean body mass $230 \pm 20 \mathrm{~g}$ ) were obtained from the Experimental Animal Center of the Dalian Medical University (China). Sixty animals were randomly selected and divided into six groups. Rats of three L-Arg-treated groups were i.p. injected with 10,40 , and $160 \mathrm{mg} / \mathrm{kg}$ L-Arg twice a day for 5 days, respectively. Animals the KA-treated group were i.p. injected with $10 \mathrm{mg} / \mathrm{kg}$ KA once on the 6 th day after L-Arg pretreatment. The normal control and negative control groups were injected with physiological saline $(2 \mathrm{ml} / \mathrm{kg})$ at the same time as the groups mentioned above.

Behavioral Observations. All rats injected with $10 \mathrm{mg} / \mathrm{kg}$ KA demonstrated brisk rotational 
movements of the head and trunk called "wet dog shakes" (WDSs). The onset of seizures and the degree of their severity were estimated using a point scale proposed by Racine [12]: 1, chewing; 2, head nodding; 3 , unilateral forelimb clonus; 4 , rearing with bilateral forelimb clonus; and 5, rearing with bilateral forelimb clonus and falling back. Behavior of KA-treated rats was monitored for $3 \mathrm{~h}$ after KA administration.

Immunohistostaining. After observing seizure behavior, the rats were i.p. anesthetized with pentobarbitone and perfused transcardially with 4\% paraformaldehyde. The brains were removed and immersed in $20 \%$ sucrose diluted in $0.1 \mathrm{M}$ phosphatebuffered saline (PBS, pH 7.4). Brain samples were cut into $50-\mu \mathrm{m}$-thick slices. The latter were first rinsed in PBS for $10 \mathrm{~min}$ and then consequently incubated with bovine serum albumin (BSA) for $30 \mathrm{~min}$, incubated with the primary GFAP antibody $(1: 3,000)$ overnight at $4{ }^{\circ} \mathrm{C}$, rinsed in PBS for $10 \mathrm{~min}$, and then incubated with biotinylated goat anti-rabbit serum (1:500) and avidinbiotin complex $(\mathrm{ABC})$ for $3 \mathrm{~h}$. Diaminobenzidine (DAB) provided visualization of staining. Control sections were incubated with PBS instead of the primary antibody.

Pathological Image Analysis. A HPIAS series colorful pathology photograph system was used to analyze GFAP-immunopositive (ip) cells. The testsquares in the screen of the microscope used were $194258 \mu^{2}$, and the number and average optical density of GFAP-ip cells were measured within these squares.

Western Blotting Analysis. Hippocampal samples were removed, weighed, homogenized in Tris buffer saline (TBS, $\mathrm{pH} 7.5$ ) for $15 \mathrm{sec}$, and then vigorously vortexed for $10 \mathrm{sec}$. Parts of the homogenized samples $(100 \mu \mathrm{l})$ were heated at $100^{\circ} \mathrm{C}$ for $5 \mathrm{~min}$ and then centrifuged at 13,000 rpm for $5 \mathrm{~min}$. Ten microliters of the supernatant were used for quantifying protein according to the Smith's method [11]. Another $100 \mu \mathrm{l}$ of homogenized samples were added to an equal volume of the sample loading buffer, heated at $100^{\circ} \mathrm{C}$ for $5 \mathrm{~min}$, and then centrifuged at $13,000 \mathrm{rpm}$ for $5 \mathrm{~min}$. After these procedures, electrophoresis, transferring, and identifying were carried out. Markers were cut away from the membrane, stained, destained, and dried, while the other part of the membrane was washed twice with TBS for $10 \mathrm{~min}$ and then immobilized by $1 \%$ BSA for $1 \mathrm{~h}$. Next operations were incubation with the primary antibody against GFAP $(1: 1,500)$ and subsequent incubation with the secondary antibody and $\mathrm{ABC}$ for $1 \mathrm{~h}$. Finally, photographs were taken and analyzed.

Statistics. The numerical results are shown as means \pm s.d., and the one-way ANOVA test was used to evaluate the statistical significance $(P<0.05)$.

\section{RESULTS}

Behavior. The KA-treated rats in the model group exhibited clear time-dependent seizure behavior. Five minutes after KA injection, staring and WDSs occurred during $30 \mathrm{~min}$ to $1 \mathrm{~h}$. Spontaneous stereotyped seizure behavior happened within a 1- to 3-h-long interval; this was characterized by rearing on the hindlimbs with bilateral clonus, until the balance was lost. In comparison with the control group, animals of the $160 \mathrm{mg} \mathrm{L}-\mathrm{Arg}+10 \mathrm{mg} / \mathrm{kg} \mathrm{KA}$-injected group showed much longer WDS latencies with no significant differences in the rearing latency and seizure scores. However, $40 \mathrm{mg} / \mathrm{kg} \mathrm{L}$-Arg + KA-treated rats showed much longer WDS latencies and rearing latencies with lower seizure scores, while $10 \mathrm{mg} / \mathrm{kg} \mathrm{L-Arg}+\mathrm{KA}-$ treated group showed no significant changes. These results suggested that $10 \mathrm{mg} / \mathrm{kg}$ L-Arg could alleviate the normal condition only mildly, while $40 \mathrm{mg} / \mathrm{kg}$ L-Arg alleviated the condition obviously. This proved that the effect of L-Arg on abnormal behavior induced by KA is dose-dependent, and that the optimum dose of L-Arg is about $40 \mathrm{mg} / \mathrm{kg}$, as illustrated in Table 1 .

Table 1. Effects of Different Doses of L-Arginine (L-Arg) on Kainic Acid (KA)-Induced Seizure Behavior in Rats

T а б л и ц я. 1. Вплив L-аргініну на прояви судом, викликаних дією каїнової кислоти

\begin{tabular}{l|c|c|c}
\hline \multicolumn{1}{c|}{$\begin{array}{c}\text { Animal groups injected with } \\
\text { different agents }\end{array}$} & WDS latency, min & Rearing latency, min & Score of seizures \\
\hline $2 \mathrm{ml} / \mathrm{kg} \mathrm{PS}+10 \mathrm{mg} / \mathrm{kg} \mathrm{KA}$ & $26.44 \pm 1.21$ & $77 \pm 2.17$ & $23.19 \pm 0.83$ \\
$10 \mathrm{mg} / \mathrm{kg} \mathrm{L-Arg}+10 \mathrm{mg} / \mathrm{kg} \mathrm{KA}$ & $25.12 \pm 1.06$ & $76 \pm 2.20$ & $22.17 \pm 0.79$ \\
$40 \mathrm{mg} / \mathrm{kg} \mathrm{L}-\mathrm{Arg}+10 \mathrm{mg} / \mathrm{kg} \mathrm{KA}$ & $33.75 \pm 1.29^{* *}$ & $90 \pm 3.15^{* *}$ & $16.25 \pm 0.77^{* *}$ \\
$160 \mathrm{mg} / \mathrm{kg}$ L-Arg $+10 \mathrm{mg} / \mathrm{kg} \mathrm{KA}$ & $34.62 \pm 1.73^{* *}$ & $89 \pm 4.55$ & $21.35 \pm 0.63$ \\
\hline
\end{tabular}

Footnotes. **Significant difference from physiological saline (PS) + KA-injected group with $P<0.01(n=10)$. WDS) "Wet dog shakes" (brist rotational movements of the head and trunk). 
Immunohistostaining Analysis. In comparison with the control group, the number and the density of GFAP-ip astrocytes in KA-treated rats were significantly greater in the hilus of the dorsal hippocampus. A bandlike distribution of astrocytes was clearly observed, the general intensity of staining of the GFAP-ip units was markedly greater, and strongly labeled immunoreactive elements were almost entirely located in the hilus and adjacent regions. A majority of the GFAP-ip cells appeared larger and were stained more heavily, with positive processes appearing more clearly. However, $40 \mathrm{mg} / \mathrm{kg} \mathrm{L}$-Arg + KA-treated rats demonstrated noticeably weaker overexpression of GFAP-ip astrocytes mentioned above; there was no statistically significant difference from the expression in the control groups (Fig. 1 and Table 2).

TABLE 2. Numbers of GFAP-ip Astrocytes and Pathological Image Analysis in the Hilus of the Rat Dorsal Hippocampus

Т а б л и ц я 2. Кількість GFAP-імунопозитивних астроцитів та прояви патологічних змін у хілусі дорсального гіпокампа щурів



Footnotes. N) Number of positive cells, S) surface area of the positive bodies, D) average optical density, and ID) integral optical density per one sight region $\left(194,258 \mu \mathrm{m}^{2}, n=15-20\right.$ sections). * Significant difference from the control PS-injected group at $P<0.05$. $* *$ Significant difference from the control PS-injected group at $P<0.01$. ${ }^{\#}$ Significant difference from the PS + KA-injected group at $P<0.01$. Other designations are the same as in Table 1.
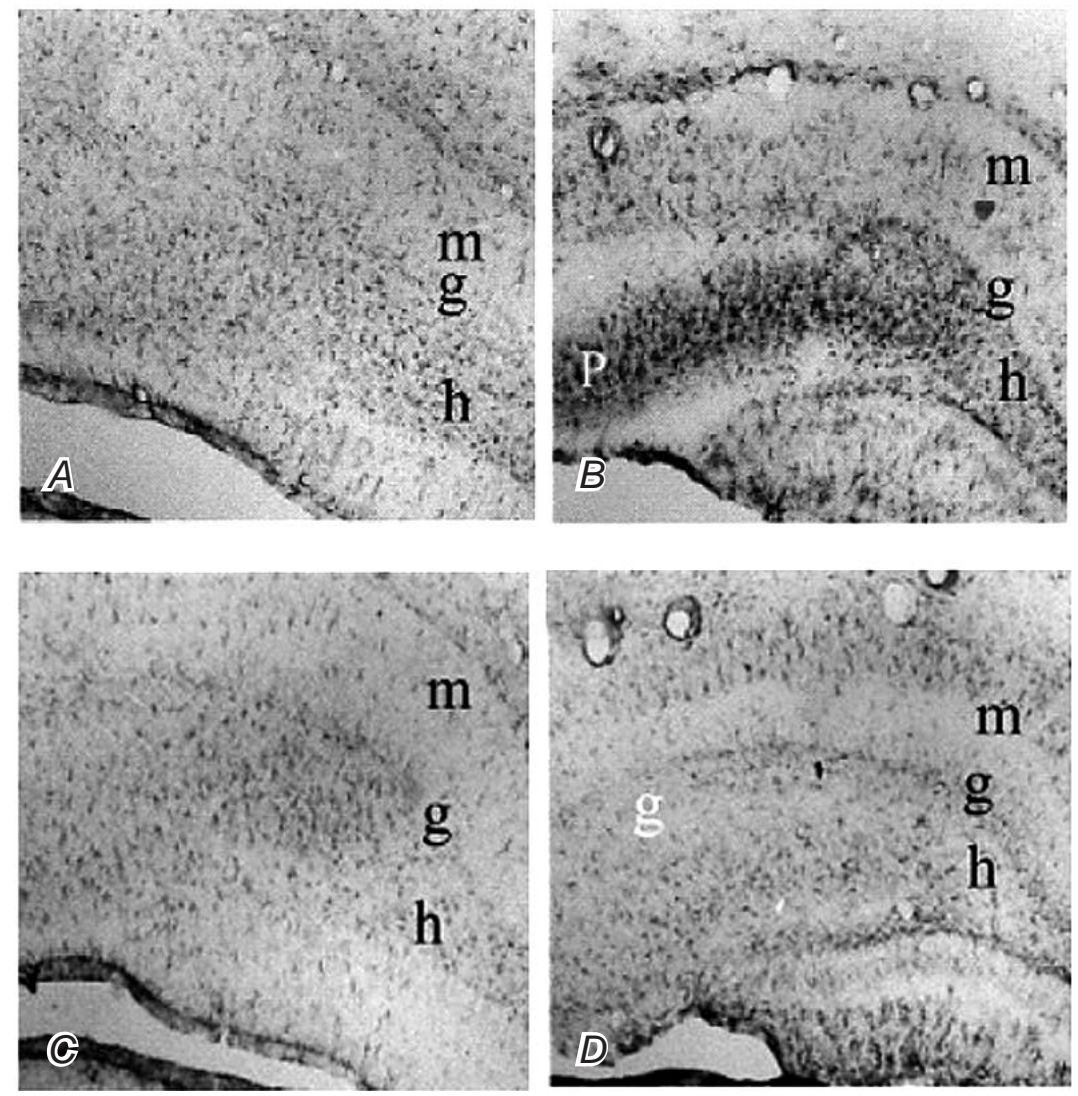

F i g. 1. Effect of $40 \mathrm{mg} / \mathrm{kg}$ L-arginine (L-Arg) on expression of GFAP-ip astrocytes in the rat dorsal hippocampus. A-D) Hippocampal slices obtained from a control animal injected with physiological saline $(2 \mathrm{ml} / \mathrm{kg}, \mathrm{A})$, a $10 \mathrm{mg} / \mathrm{kg}$ kainic acid (KA)treated rat (B), an L-Arg-injected animal (C), and a $\mathrm{KA}+\mathrm{L}$-Arg-treated animal. $\mathrm{m}$ and g) Molecular and granular layers of the dentate gyrus, respectively; h) hilus of the dentate gyrus, and p) stratum pyramidale of the $C A 3$.

Р и с. 1. Вплив 40 мг/кг L-аргініну на експресію гліального фібрилярного кислого протеїну (GFAP) в астроцитах дорсального гіпокампа щура. 


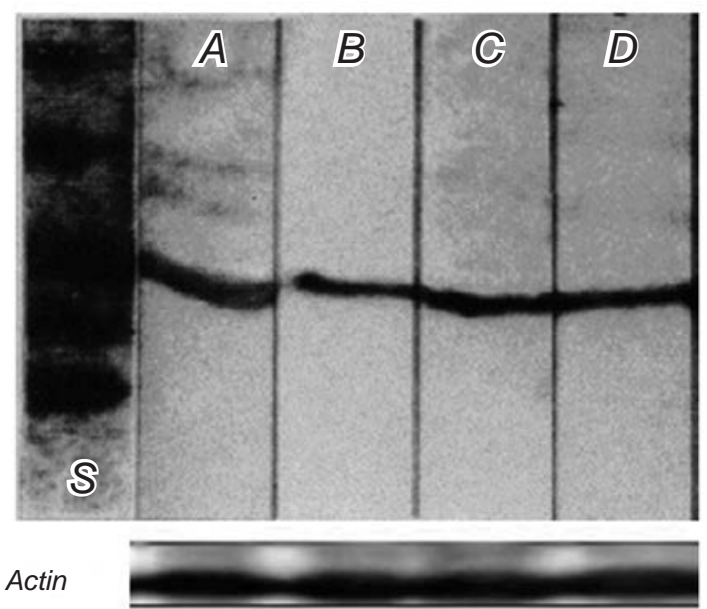

F i g. 2. Expression of GFAP in the rat hippocampus demonstrated using Western blot analysis. A) Control (physiological salineinjected) group, B) KA-treated rats, C) $40 \mathrm{mg} / \mathrm{kg}$ L-Arg-injected animals, and D) KA $+40 \mathrm{mg} / \mathrm{kg}$ L-Arg-treated group. S) Standard molecular mass $(\mathrm{kDa})$ of the markers, from top to bottom, 97.4 (phosphorylase), 66.2 (bovine serum albumin), 55.0 (glutamate dehydrogenase), 42.7 (ovalbumin), and 40.0 (aldolase). Each lane showes an identical major band stained strongly at about $50 \mathrm{kDa}$ position.

Р и с. 2. Експресія GFAP у гіпокампі щурів: результати Вестернблотингу.

Western Blotting Analysis. The molecular mass of GFAP is about $50 \mathrm{kDa}$. Three hours after KA injection, GFAP expression was obviously more intense in the PS-treated + KA-injected group. At the same time, such expression in the $40 \mathrm{mg} / \mathrm{kg} \mathrm{L}-\mathrm{Arg}+\mathrm{KA}-\mathrm{rats}$ was noticeably weaker and showed no significant difference $v s$ that in the PS-injected group (Figs. 2 and $3)$. These results are fully comparable with those obtained in the immunohistostaining experiments.

\section{DISCUSSION}

Nitric oxide has been implicated in mediation of neuronal excitotoxic injury [14-15]. L-arginine (the substrate for NO synthesis), regarded as the main endogenous source for NO production, was used in our experiments to study the role of NO in generation of seizures in KA-treated rats. It was reported earlier that pretreatment with L-Arg tends to potentiate the effects of quinolinic acid (QA) and induces clonic and tonic convulsions in mice [16]. Simultaneously,

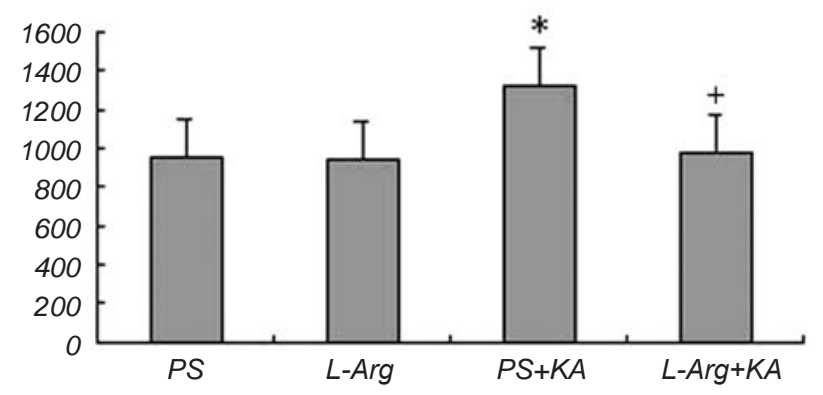

F i g. 3. Results of scanning of hippocampal GFAP expression $(n=6)$. L-Arg) L-arginine, KA) kainac acid. * Significant difference from the control physiological saline-injected group (PS) at $P<0.05$. ${ }^{+}$Significant difference from PS + KA-treated group at $P<0.05$. Vertical scale) Relative optical density.

Р и с. 3. Результати сканування при дослідженні експресії GFAP у гіпокампі щурів.

the effects of L-Arg on seizure activity elicited by KA are dose-dependent and contribute to the genesis of seizure activity [17]. At the same time, it was found that L-Arg did not affect kindling or seizure severity [18]. Other studies showed that NO might act as an endogenous anticonvulsant in mice [19-20], and the anticonvulsant L-Arg alone significantly increases the NO concentration and NOS activity in specific brain regions responsible for suppression of convulsions [21-22]. Previous studies, however, indicated that KA-induced seizures appeared later in rats pretreated with a single large dose of L-Arg [18-21].

Due to all the above-mentioned controversies, we investigated the effects of chronic treatment with small doses of L-Arg on KA-induced seizures. The results showed that pretreatment with $40 \mathrm{mg} / \mathrm{kg}$ L-Arg clearly alleviated KA-induced seizures, while pretreatment with the lower $(10 \mathrm{mg} / \mathrm{kg})$ or greater $(160 \mathrm{mg} / \mathrm{kg})$ doses of L-Arg demonstrated less significant effects. Thus, the dose dependence is probably U-like. We also observed that chronic treatment with moderate doses of L-Arg ( $40 \mathrm{mg} / \mathrm{kg})$ exhibited anticonvulsant effects.

The results presented here indicate that chronic treatment with moderate doses of L-Arg $(40 \mathrm{mg} / \mathrm{kg})$ provide an anticonvulsant action, but the mechanism of such effect still remains unclear. Astrocytes perform a variety of functions in the adult CNS [2324]. Reactive gliosis is a response of astrocytes to a variety of insults that is characterized by hypertrophy 
of the cell bodies and processes and an increase in the expression of GFAP [25-26]. Previous studies revealed that a single convulsive KA-induced seizure episode strongly intensifies GFAP expression in astrocytes in the hippocampal formation. Bennett et al. reported that GFAP immunopositivity was enhanced in the hippocampus and correlative brain areas $3 \mathrm{~h}$ after KA injection, but the specific distribution and alteration were not described [27, 28]. Our results showed that GFAP expression after L-Arg pretreatment reduced KA-challenged seizure behavior. Furhtermore, L-Arg pretreatment with the dosage of $40 \mathrm{mg} / \mathrm{kg}$ inhibited hyperplasia and hypertrophy of the astrocytes and bandlike distribution of these glial cells and also alleviated the abnormal overexpression of GFAP induced by KA.

Thus, our study suggests that the effect of NO on KA-induced seizures is dose-dependent, and that the L-Arg dose of $40 \mathrm{mg} / \mathrm{kg}$ seems to be optimum for correction of KA-induced abnormal behavior. The effect may be related to regulation of the expression of GFAP and to a protecting action with respect to astrocytes. In future, we will try to block NO expression and to observe behavioral changes and changes in astrocytes in KA-treated animals. It is necessary to be sure that NO is the key point for curing KA-induced seizures and to make clear the possible mechanism of the action of the optimum L-Arg dose $(40 \mathrm{mg} / \mathrm{kg})$, which most effectively reduced abnormal behavior in KA-treated rats.

Йі. Сун Йо. Лiaн ${ }^{1}$, Ч. Сун ${ }^{2}$

\section{ВПЛИВИ L-АРГІНІНУ НА СУДОМНІ ПОВЕДІНКОВІ ПРОЯВИ ТА ЕКСПРЕСІЮ GFАР, ЗУМОВЛЕНІ ВВЕДЕН- НЯМ КАЇНОВОЇ КИСЛОТИ ЩУРАМ}

\footnotetext{
${ }^{1}$ Далянський медичний університет (Китай).

${ }^{2}$ Інститут із дослідження патології мозку Далянського медичного університету (Китай).

P е 3 ю м е
}

Поведінка щурів, яким внутрішньоочеревинно ін'єкували 10 мг/кг каїнової кислоти (КК), характеризувалася вираженими проявами судом, „струшуваннями мокрого собаки”, вставанням на задні кінцівки та білатеральним клонусом. Попередні введення L-аргініну (L-Aрг) двічі на день протягом п'яти днів забезпечували істотне зменшення інтенсивності таких проявів. Було виявлено, що доза L-Aрг 40 мг/кг є близькою до оптимальної; дози 10 та 160 мг/кг справляли менш виражену позитивну дію. У щурів, яким уводили КК, у хілусі дорсального гіпокампа спостерігалася більш висока щільність астроцитів, імунопозитивних щодо гліального фібрилярного кислого білка (GFAP), у той час як у щурів, котрим уводили КК сумісно із 40 мг/кг L-Арг, експресія GFAP була виражена в помітно меншій мірі. Результати досліджень з використанням Вестерн-блотингу були повністю співставними 3 даними, отриманими в експериментах з імуногістологічним міченням.

\section{REFERENCES}

1. H. Tapiero, G. Mathé, P. Couvreur, and K. D. Tew, "I. Arginine," Biomed. Pharmacother., 56, No. 9, 439-445 (2002).

2. G. Wu, L. A. Jaeger, F. W. Bazer, and J. M. Rhoads, "Arginine deficiency in preterm infants: biochemical mechanisms and nutritional implications," J. Nutr. Biochem., 15, No. 8, 442451 (2004).

3. Y. P. Sun, C. K. Sun, M. Fan, et al., "Effect of NO mediator on kainic acid-induced behavioral seizures in rats," Chin. J. Appl. Physiol. (in Chinese), 19, Issue 2, 185-188 (2003).

4. J. B. Gramsbergen and K. J. van den Berg, "Regional and temporal profiles of calcium accumulation and glial fibrillary acidic protein levels in rat brain after systemic injection of kainic acid," Brain Res., 667, No. 2, 216-228 (1994)

5. B. Adams, L. E. Von, and L. Vaccarella, "Time course for kindling-induced changes in the hilar area of the dentate gyrus: reactive gliosis as a potential mechanism," Brain Res., 804, No. 2, 331-336 (1998).

6. P. Santofimia-Castaño, G. M. Salido, and A. Gonzalez, "Ethanol reduces kainate-evoked glutamate secretion in rat hippocampal astrocytes," Brain Res., 1402, 1-8 (2011).

7. M. Carballo-Quintás, I. Martínez-Silva, C. Cadarso-Suárez, et al., "A study of neurotoxic biomarkers, c-Fos and GFAP, after acute exposure to GSM radiation at $900 \mathrm{MHz}$ in the picrotoxin model of rat brains," Neurotoxicology, 32, No. 4, 478-494 (2011).

8. Y.-P. Sun, W.-Q. Zhang, and J.-S. Hong, "The changes of glial fibrillary acidic protein(GFAP)-immunoreactivity in the seizure sensitive rat brain," Chin. J. Neurosci. (in Chinese), $\mathbf{3}$, No. 2, 73-78 (1996).

9. E. R. Torre, E. Lothman, and O. Steward, "Glial response to neuronal activity: GFAP-mRNA and protein levels are transiently increased in the hippocampus after seizures," Brain Res., 631, No. 2, 256-264 (1993).

10. O. Steward, "Electroconvulsive seizures upregulate astroglial gene expression selectively in the dentate gyrus," Mol. Brain Res., 25, Nos. 3/4, 217-224 (1994).

11. L. C. V. Baille and J. M. Collombet, "Early regional changes of GFAP mRNA in rat hippocampus and dentate gyrus during soman-induced seizures," NeuroReport, 7, No. 1, 365-369 (1995).

12. R. J. Racine, "Modification of seizure activity by electrical stimulation," Electroencephalogr. Clin. Neurophysiol., 32, No. 3, 281-294 (1972).

13. M. J. Dunn, "Determination of total protein concentration," in: Protein Purification Methods. A Practical Approach, IRL Press, Oxford (1989), pp. 10-18.

14. A. Lumme, S. Soinila, M. Sadeniemi, et al., "Nitric oxide synthase immunoreactivity in the rat hippocampus after status 
epilepticus induced by perforant pathway stimulation," Brain Res., 871, No. 2, 303-310 (2000).

15. L. Zhou and D. Y. Zhu, "Neuronal nitric oxide synthase: Structure, subcellular localization, regulation, and clinical implications," Nitric Oxide, 20, No. 4, 223-230 (2009).

16. T. A. Nakamura, K. Yamada, T. Hasegawa, and T. Nabeshima, "Possible involvement of nitric oxide in quinolinic acidinduced convulsion in mice," Pharmacol. Biochem. Behav., 51, Nos. 2/3, 309-312 (1995).

17. G. De Sarro, E. D. Di Paola, A. De Sarro, and M. J. Vidal, "L-arginine potentiates excitatory amino acid-induced seizures elicited in the deep prepiriform cortex," Eur. J. Pharmacol., 230, No. 2, 151-158 (1993).

18. L. J.Herberg, A. Grottick, and I. C. Rose, "Nitric oxide synthesis, epileptic seizures and kindling," Psychopharmacology, 119, No. 1, 115-123 (1995).

19. E. Przegalinski, L. Baran, and J. Siwanowicz, "The role of nitric oxide in the kainate-induced seizures in mice," Neurosci. Lett., 170, No. 1, 74-76 (1994).

20. A. Lesani, M. Javadi-Paydar, T. K. Khodadad, et al., "Involvement of the nitric oxide pathway in the anticonvulsant effect of tramadol on pentylenetetrazole-induced seizures in mice," Epilepsy Behav., 19, No. 3, 290-295 (2010).

21. A. R. Jayakumar, R. Sujatha, V. Paul, et al., "Involvement of nitric oxide and nitric oxide synthase activity in anticonvulsive action," Brain Res., 48, No. 4, 387-394 (1999).

22. A. Bahremand, P. Ziai, T. K. Khodadad, et al., "Agmatine enhances the anticonvulsant effect of lithium chloride on pentylenetetrazole-induced seizures in mice: Involvement of L-arginine/nitric oxide pathway," Epilepsy Behav., 18, No. 3, 186-192 (1010).

23. N. Otani, H. Nawashiro, N. Nomura, et al., "A role of glial fibrillary acidic protein in hippocampal degeneration after cerebral trauma or kainate-induced seizure," Acta Neurochir., Suppl., 86, 267-269 (2003).

24. A. Sharif and V. Prevot, "ErbB receptor signaling in astrocytes: A mediator of neuron-glia communication in the mature central nervous system," Neurochem. Int., 57, No. 4, 344-358 (2010).

25. J. L. Stringer, "Repeated seizures increase GFAP and vimentin in the hippocampus," Brain Res., 717, Nos. 1/2, 147-153 (1996).

26. T. Sawaguchi, F. Patricia, H. Kadhim, et al., "Clinicopathological correlation between brainstem gliosis using GFAP as a marker and sleep apnea in the sudden infant death syndrome," Early Human Dev., 75, Suppl., S3-11 (2003).

27. S. A. Bennett, B. Stevenson, W. A. Staines, and D. C. Roberts, "Periodic acid-Schiff (PAS)-positive deposits in brain following kainic acid-induced seizures: relationships to fos induction, neuronal necrosis, reactive gliosis, and blood-brain barrier breakdown," Acta Neuropathol., 89, No. 2, 126-138 (1995)

28. N. Otani, H. Nawashiro, S. Fukui, et al., "Enhanced hippocampal neurodegeneration after traumatic or kainite excitotoxicity in GFAP-null mice," J. Clin. Neurosci., 13, No. 9, 934-938 (2006). 